\title{
El sector inmobiliario y las crisis económicas
}

\begin{abstract}
Antonio Daher. Pontificia Universidad Católica de Chile, Santiago, Chile.
RESUMEN | La creciente urbanización de la economía y la doble concentración económica y territorial- de los sectores inmobiliario y financiero en las metrópolis, fundamentan la relación entre los ciclos inmobiliarios y las crisis económicas detonadas por sus burbujas, la alta incidencia macroeconómica del sector inmobiliario y su rol articulador entre el sector financiero y la economía real. Antes de la última crisis (2008), las instituciones financieras y fondos de inversión inmobiliaria transnacionales encontraron en la financiarización y titulización una vía eficaz para su diversificación geográfica y distribución del riesgo hipotecario. Fue también la vía expedita del contagio de una crisis con ubicuidad financiera, aunque no social ni territorial. Las hipotecas subprime fueron para las minorías marginadas en los barrios con más hispanos, negros, inmigrantes y pobres: la vivienda social estadounidense, financiarizada, "inmobiliarizó" al sector financiero y desfinanciarizó la banca internacional, en una crisis global con dramáticas consecuencias sociales y políticas.
\end{abstract}

Palabras ClaVe | crisis económica, sector inmobiliario.

ABSTRACT | The growing urbanization of the economy and the double concentration (economic and territorial) of the real estate and financial sectors within major metropolises provide the basis of the relation between real estate cycles, the economic crises brought on by bubbles on the real estate sector, the high degree of macroeconomic influence by the real estate sector, and the role of this sector as the mediator between the financial sector and the real economy. Before the latest financial crisis in 2008, financial institutions and transnational real estate investment funds found an efficient road to geographic diversification and mortgage risk distribution through financialization and securitizacion. Coincidentally, this was also the clearest pathway for the contagion of a crisis that was financially ubiquitous, although not socially or territorialy so. The subprime mortgages were granted to marginalized minorities in neighborhoods made up for the most part by Hispanics, African Americans, immigrants and lower-class populations: American social housing, having been financialized, infected the financial sector with real estate mortgagebacked securities, which ended up definancializing the international banking sector in a global crisis with dramatic social and political consequences.

KEY WORDS | economic crisis, real estate market.

Recibido el 6 de agosto de 2012, aprobado el 12 de febrero de 2013

E-mail: adaher@uc.cl 


\section{Introducción}

La relación entre el sector inmobiliario y las crisis económicas constituye el centro de esta investigación. Su objetivo principal es analizar, más que el conocido efecto de los períodos de contracción económica en la actividad de la construcción y en los mercados de la vivienda, de suelos y de bienes raíces en general, la incidencia del sector inmobiliario como una causa clave y recurrente de las crisis económicas locales y globales.

Consecuentemente, la hipótesis central que busca verificar esta investigación sostiene que la economía inmobiliaria, por su habitualmente alta participación en el producto y en el empleo, y por su rol estratégico de articulación entre el sector financiero y la economía real, es un factor determinante y detonante de los ciclos de auge y recesión y de las crisis económicas.

Las imperfecciones inherentes a los mercados inmobiliarios, la especulación asociada a las externalidades y plusvalías urbanas y los factores de riesgo propios del crédito y de los valores hipotecarios incrementan los efectos distorsionadores que dichos mercados tienen, no pocas veces, en los procesos de crecimiento y contracción. Se trata de una distorsión que se manifiesta en la emergencia reiterada de burbujas inmobiliarias y en sus consecuencias multisectoriales, debido a encadenamientos productivos, de insumos y de servicios, y sus apalancamientos y derivados financieros.

Por su parte, el sector inmobiliario suele ser uno de los más expuestos y sensibles a las políticas monetarias, a los flujos privados y estatales de inversión externa, a las colocaciones de los fondos de inversión -incluidos los previsionales y de seguros-, a la oferta crediticia hipotecaria, a los mercados de valores e, incluso, al lavado de dinero y blanqueo de capitales.

En síntesis, el sector inmobiliario resulta ser macroeconómicamente clave, cuantitativa y cualitativamente, por sus complejas relaciones intersectoriales y por su muy significativa ponderación en las variables e indicadores productivos y financieros. No casualmente los gobiernos recurren a él como instrumento para incentivar la economía e incrementar el empleo.

Metodológicamente, esta investigación se desarrolla y fundamenta en tres ámbitos complementarios: histórico, teórico y cuantitativo.

El primero, explorado a partir de la literatura especializada, cubre las principales crisis globales desde el siglo XIX hasta las secuelas aún presentes de la conocida como subprime. Esta perspectiva histórica, que geográficamente incluye crisis europeas, americanas y asiáticas, confirmará el rol decisivo de la economía inmobiliaria en la mayoría de ellas.

El segundo ámbito de análisis, de índole más teórico, revisa las aproximaciones conceptuales de reconocidos economistas -entre ellos varios "nobeles"- y de otros expertos al estudio de las diversas crisis y sus causales inmobiliarias. Esta investigación hará una síntesis de tales aportes y fundamentará así sus hipótesis. 
En el tercer ámbito metodológico, de carácter cuantitativo, se revisará una amplia y elocuente variedad de indicadores estadísticos -información secundaria de fuentes oficiales y de especialistas- que, verificando la alta relevancia macroeconómica y financiera del sector inmobiliario, complementará la evidencia histórica y el análisis teórico de la investigación.

Los resultados y conclusiones, además de contrastarse con las hipótesis iniciales, referirán a las dramáticas y gravísimas consecuencias sociales -recesión con desempleo masivo, incremento de la pobreza, caída de la demanda y del consumo, desalojos por ejecución hipotecaria, migraciones...- y, por cierto, también a sus no menos graves efectos políticos: movimientos sociales, paros y protestas; impopulares ajustes en las políticas públicas y presupuestos fiscales; cuestionamiento y puesta en jaque a las instituciones monetarias supranacionales; e, incluso, caídas de algunos gobiernos.

La estrecha relación entre los ciclos inmobiliarios y las coyunturas de crisis remite a una relación más estructural: la creciente urbanización no solo de la población, también de la economía y, más aún, la concentrada metropolización de las economías inmobiliarias y financieras y de su maridaje. "La capital: el capital" es una expresión inequívoca de la concentración territorial de una economía cada vez más terciarizada e hiperurbanizada y de la "metromonopolización" financieroinmobiliaria.

El mercado inmobiliario y en especial las grandes empresas del sector, el sistema financiero y los fondos inmobiliarios transnacionales se constituyen en la gerencia y la manufactura de la "infraestructura" de las ciudades capitales y globales. Tales empresas y fondos, intentando diversificar geográficamente sus inversiones, encontraron en la financiarización -y particularmente en la titulización- un vehículo eficaz de distribución y dispersión del riesgo de sus portafolios. Sin embargo, la financiarización y sus instrumentos derivados se convirtieron, paradójicamente, en el canal más expedito de contagio territorial de la crisis. La financiarización, haciendo más líquido, transable y móvil lo inmobiliario, permitió la ubicuidad -ifinanciera, no territorial!- de las hipotecas de alto riesgo.

El "dónde" de las subprime refiere ni más ni menos que a la localización urbana y metropolitana de las minorías más pobres y marginadas de los Estados Unidos -comunidades étnicas, inmigrantes, homeless-: "hipotecas basura”, en el léxico especializado. De los barrios y guetos preferentes para los préstamos subprime -con más hispanos, negros y pobres- la crisis se contagió, vía titulización inmobiliaria, al litoral andaluz de hipotecas prime e incluso superprime... y la crisis se hizo multisectorial, multinacional e hiperglobal: la vivienda social para las minorías de los Estados Unidos, financiarizada, terminó desfinanciarizando la banca internacional y la economía global. Crisis generalizada, pero territorial y socialmente desigual: más aguda en los países "periféricos" de la eurozona; más dolorosa para el 16\% de pobres de la mayor economía del mundo -cerca de 50 millones en Estados Unidos-, más injusta para el $24 \%$ de españoles sin trabajo... 
La economía inmobiliaria, causa concurrente y detonante de muchas de las crisis -en especial de las más graves y de la de 2008, la más global de todas y aún persistente- se perfila así en toda su complejidad e incidencia macroeconómica, social y política, y en su marcado efecto territorial y gran impacto urbano y metropolitano.

\section{Ciclos inmobiliarios y crisis económicas: aproximación histórica}

En un exhaustivo estudio que abarca más de ochocientos años de historia de crisis económicas -desde el default inglés del siglo XIV a la crisis subprime en Estados Unidos, incluyendo sesenta y seis países de cinco continentes-, Reinhart y Rogoff (2011) elaboran una tipología de aquellas y constatan importantes regularidades empíricas. Entre sus descubrimientos principales destacan que ciclos significativos de incremento en la movilidad internacional de capitales producen crisis bancarias; que el sobreendeudamiento interno o doméstico incide decididamente, junto a la deuda gubernamental, como factor de crisis en muchos países; y que estas con frecuencia emanan de los centros financieros y se transmiten mediante shocks en las tasas de interés y colapsos en los precios de los commodities, produciendo así, a partir de los países centrales, crisis de deuda soberana en otros. Con todo, uno de los hallazgos más notables del estudio mencionado y más enfatizado por sus autores es la relación generalizada y persistente entre las crisis bancarias -en especial las de las últimas décadas y las más graves- y los ciclos en los precios de las acciones y, sobre todo, de la vivienda.

Explorando la relación de elementos comunes en las crisis, Roubini y Mihm (2010) repasan la burbuja especulativa de los tulipanes en Holanda en la década de 1630, la burbuja del Mar del Sur en 1720, la primera crisis financiera global en 1825, la de 1907 y la Gran Depresión de los treinta iniciadas en Estados Unidos y las múltiples crisis posteriores a los ochenta, recurriendo a explicaciones conceptuales desde Keynes hasta Minsky.

Los mismos autores (Roubini \& Mihm, 2010) destacan cómo, ya desde el siglo XIX y de manera reiterada, la valorización y especulación territoriales producidas por la expansión ferroviaria y las burbujas inmobiliarias se perfilan como causas mediatas o inmediatas de las sucesivas crisis. En efecto, "el pánico de 1857 no fue menos global (respecto del inglés de 1825) en cuanto a su esfera de acción. El período de bonanza empezó en Estados Unidos con la especulación en torno al tráfico de esclavos, el ferrocarril, los instrumentos financieros y el suelo (...). Es posible que el hundimiento global más espectacular del siglo XIX fuera la crisis de 1873 (...) las indemnizaciones que Francia pagó a Alemania tras la guerra franco-prusiana desencadenaron un boom especulativo en el sector inmobiliario alemán y austríaco". Y también "la crisis de 1907 empezó en Estados Unidos después de que se fuera a pique un boom especulativo asociado a las acciones y al sector inmobiliario" (pp. 43-45).

Según Marichal (2010), la crisis de 1857 se origina en burbujas relacionadas con el sector de ferrocarriles y tierras públicas; la de 1873, con los sectores de la 
construcción, de la vivienda y ferrocarriles; la de 1974, con booms en acciones y bienes inmuebles, al igual que la de 1990 en Japón; y la de 2008, ciertamente con bienes inmuebles, derivados y credit default swaps (CDS) o seguros contra impago de créditos. Según este autor -y a diferencia de otros-, la primera crisis mundial es la de 1873, iniciada en Austria y expandida a gran parte de Europa y luego a los Estados Unidos con un gran desplome bursátil y financiero, reflejando así la extensión y creciente integración del capitalismo a escala internacional. Siguiendo a Giffen y Schumpeter, el mismo autor indica como causa inmediata de dicha crisis el auge y caída de un sector clave en la actividad económica a escala internacional, la construcción ferroviaria: los contratistas congelaron las obras de construcción en EE.UU., Europa y otras regiones, con el consiguiente despido de millones de trabajadores y la cancelación de contratos de suministros metalúrgicos y mineros (Marichal, 2010).

Las primeras crisis del siglo XX confirman e incrementan la relación entre los sectores inmobiliarios -incluidas propiedades urbanas y tierras agrícolas- y financieros, y su vinculación con los centros económicos. En efecto, la crisis de 1907 se originó en instituciones de Nueva York semejantes a los bancos, aunque orientadas en principio a administrar herencias y propiedades. Estos "fideicomisos" tenían menos regulaciones que los bancos nacionales, pero comenzaron a especular en finca raíz y la bolsa, áreas prohibidas a aquellos, pagando rendimientos más altos y creciendo rápidamente. "Para 1907, el valor total de los activos de los fideicomisos de la ciudad de Nueva York era tan grande como el total de los bancos nacionales (...). El Pánico de 1907 comenzó con la desaparición del fideicomiso Knickerbacker..." (Krugman, 2010, p. 161).

Por su parte, Rajan y Ramcharan (2011) verifican que la extraordinaria proliferación bancaria -y del crédito- en las tres primeras décadas del siglo XX en los Estados Unidos ejerció en los activos un efecto precio muy superior al causado por las variables fundamentales. Particular interés tiene esta constatación para las tierras agrícolas, cuya deuda hipotecaria medida por acre aumentó $135 \%$ entre 1910 y 1920 , anticipando las cerca de seis mil quiebras bancarias $-20 \%$ de los bancos- en los años siguientes que precedieron a la Gran Depresión.

La expansión crediticia y el endeudamiento inducen prácticas especulativas en los mercados inmobiliario y bursátil, con alternancia secuencial o simultaneidad, que luego se expresan en burbujas más o menos locales o globales. Ilustra este proceso la crisis originada en Florida pocos años antes de la Gran Depresión. Luego de la Primera Guerra Mundial y de sus consecuencias en el dinamismo económico, los bancos norteamericanos otorgaban generosos préstamos a quienes deseaban endeudarse para adquirir propiedades o títulos. A partir de 1919, el entusiasmo de los más pudientes se orientó a los bienes inmobiliarios de Florida. En 1926, la demanda inmobiliaria empezó a disminuir, aunque los precios seguían al alza: "se desató entonces un mecanismo que volveríamos a ver más tarde: falso optimismo, bancos que aconsejaban inversiones desproporcionadas (...), una burbuja inmobiliaria seguida de una burbuja en el mercado de acciones...” (Attali, 2009, p. 24). 
Robert Shiller, uno de los economistas más expertos en vivienda, escribiendo luego de la crisis subprime de 2008, se refiere al período de la Gran Depresión afirmando que "la última gran crisis de la vivienda en Estados Unidos se inició entre 1925 y 1933. Los precios de las casas cayeron un treinta por ciento en ese intervalo" (Shiller, 2009, p. 20). El Congreso de Estados Unidos creó en 1938 la Asociación Federal de Préstamos Hipotecarios Nacionales -luego conocida por el apodo de Fannie Mae, su nombre oficial actual-, organismo que fortaleció la industria hipotecaria e impulsó las garantías de seguridad de las hipotecas (Shiller, 2009). Esta institución pionera - una suerte de banco público- fue propuesta por Roosevelt para compartir los riesgos del sector de la vivienda (Attali, 2009). Ella misma adquirirá un rol protagónico en la crisis de las hipotecas subprime en 2008 y ejemplificará, a lo largo de su historia, la bipolaridad Estado-mercado y las oscilaciones entre regulación y liberalización.

A propósito de estos ciclos más o menos pendulares, Cortés (2000) relata la historia de las crisis del siglo XX, demostrando que en su protagonismo se produce un traslado fundamental desde el sector público al privado, acusando la falta de adecuación de los organismos internacionales ante dicho cambio. Explica el autor que luego de la Gran Depresión la tendencia general fue el incremento del tamaño y la intervención estatal, lo que implicó que las crisis en las cuatro décadas siguientes fueran casi exclusivamente de responsabilidad de los gobiernos (gasto público excesivo, políticas monetarias expansivas, consecuencias inflacionarias y cambiarias). Con los posteriores traspasos de roles al sector privado, las crisis llegaron a ser el resultado de un endeudamiento excesivo de este sector, muchas veces exacerbado por la afluencia de capitales externos: las crisis derivaron así en crisis financieras -crisis de endeudamiento- asociadas en parte a la exuberancia del sector privado que, al contrario del gobierno, no puede imprimir dinero ni cobrar más impuestos.

La crisis japonesa y del sudeste asiático en las últimas décadas del siglo pasado se relaciona con esta "exuberancia" ligada a la gran disponibilidad de crédito y a los flujos externos de capitales, evidenciando nuevamente el rol determinante de los mercados inmobiliarios.

En Japón, las inversiones especulativas en finca raíz casi provocaron una crisis bancaria en los setenta. El tamaño de la burbuja japonesa era sorprendente. A inicios de los noventa, la tierra se había encarecido extraordinariamente: "de acuerdo con un dato semificticio citado con frecuencia, la milla cuadrada sobre la que se encuentra el Palacio Imperial de Tokio valía más que todo el estado de California" (Krugman, 2010, p. 70).

"En la década de los ochenta, Japón se vio atrapado por una manía especulativa sin precedentes arraigada en los valores y el sector inmobiliario (...). El precio de los inmuebles residenciales casi se duplicó (...) y el valor de los inmuebles comerciales se triplicó" (Roubini \& Mihm, 2010, pp. 51-52). Y reflexionando sobre las consecuencias de esta burbuja, los mismos autores recuerdan que, para Japón, la década de los noventa se denominó la Década Perdida, y que ese país no volvió a crecer nunca más al ritmo previo a esa crisis. Y agregan: "En 1997 y 1998 las economías 
emergentes de todo el mundo se vieron acechadas por ese tipo de crisis (...). Los mercados de valores se sobrevaloraron, se formaron burbujas inmobiliarias" (p. 55).

A propósito de la crisis de 1997 en el sudeste asiático, Marichal (2010) expresa que la acentuada entrada de capitales indujo alzas de consideración en las bolsas y en los inmuebles en Tailandia, Malasia, Indonesia y Filipinas, y una expansión de sus sistemas bancarios. La crisis de estos y su relación con el real estate fue estrecha (Hiang Liow, 2008).

En Tailandia, cuando el país comenzó a crecer aceleradamente, "los campesinos pasaron del campo a los nuevos empleos urbanos" y los "templos de Bangkok quedaron a la sombra de torres de oficina y apartamentos". Los crecientes préstamos del exterior produjeron una gran expansión del crédito y, por ende, una ola de inversiones. "Una parte de esta tomó la forma de construcciones reales, principalmente edificios de apartamentos y oficinas, pero también hubo mucha especulación, principalmente en finca raíz y en acciones. Hacia 1996, las economías del sudeste asiático comenzaban a tener un enorme parecido con la economía 'burbuja' de Japón de finales de la década de los ochenta" (Krugman, 2010, pp. 86 y 88). Urbanización acelerada de la población y, más aún, de la economía; globalización financiera; incremento del crédito, de la demanda y las inversiones; especulación bursátil y, sobre todo, inmobiliaria en los centros urbanos más dinámicos, sedes económicas y financieras: todos factores propicios para una crisis.

"Los flujos de dinero hacia la región del sudeste asiático con frecuencia se canalizaron a través de 'fondos de mercados emergentes' que agrupaban en uno solo a todos los países (...). Su apetito por la región se había alimentado por la percepción de un 'milagro asiático' compartido por todos (...). En la mente de los inversionistas [esas economías] estaban vinculadas y consideraban los problemas de una economía como una noticia mala acerca de las otras" (Krugman, 2010, pp. 100-101). Este efecto contagio -según el mismo autor- se acusaba justo antes de la crisis de mediados de 1997: los precios de la tierra y de las acciones caían abruptamente; el bath fue dejado libre, Malasia sufría también el impacto y la rupia de Indonesia se depreciaba en $30 \%$.

Lo anterior confirma que "las recurrentes crisis han demostrado la insuficiencia del concepto e instrumental de evaluación del riesgo país. El riesgo es cada vez más propio de regiones supranacionales. La misma globalización, y los acuerdos de libre comercio y demás procesos de integración regional supranacional construidos sobre una base geográfica común, acentúan la vulnerabilidad y facilitan el contagio de las crisis al hacer más permeables las economías y diluir las fronteras nacionales" (Daher, 2004, p. 85). Algunos años antes de la crisis asiática en los Estados Unidos las entidades de ahorro y préstamo -denominadas Savings and Loan-constataron que sus préstamos se vieron afectados al estallar la burbuja inmobiliaria, hundiéndose más de 1.600 bancos que habían conservado en sus libros (según el modelo de "originar para mantener") préstamos malos para inmuebles comerciales y residenciales, lo que supuestamente no habría ocurrido -según algunos- si los préstamos se hubieran titulizado (Roubini \& Mihm, 2010). 
Una reflexión complementaria sobre esta crisis bancaria causada por el sector inmobiliario - isin la ingeniería financiera y los derivados de 2008!- acentúa incluso sus consecuencias en la recesión de inicios de los noventa. En efecto, "en los años ochenta (...) una combinación de mala suerte y malas políticas económicas llevó al fracaso de muchos bancos de ahorros y préstamos, una clase especial de bancos que se habían vuelto fuente dominante de préstamos para vivienda. Como los depósitos de esos bancos estaban asegurados por la Reserva Federal, los contribuyentes acabaron pagando la cuenta, que terminó siendo cerca del 5\% del Producto Interno Bruto (PIB) (el equivalente de más de 700.000 millones de dólares de hoy). La caída de los bancos de ahorros y préstamos llevó a una restricción de los créditos, lo que fue una causa importante de la recesión de 1990-1991" (Krugman, 2010, p. 163).

Una década después -y para compensar en parte los efectos de un desplome bursátil-, las políticas públicas instrumentalizaron el sector inmobiliario por su reconocido impacto reactivador de la economía: "en 2002, para hacer frente al descenso de la demanda (...) el gobierno de este país [EE.UU.] incitó a Freddie Mac y Fannie Mae, así como a otros financieros inmobiliarios, a otorgar préstamos a deudores menos solventes y en productos más arriesgados, los llamados subprime, con un mejor tipo de interés" (Attali, 2009, p. 42).

El mismo autor especifica y explica que los créditos hipotecarios subprime -a los deudores con peor historial de reembolso, con intereses progresivos sobre un total a veces superior al precio de la vivienda- estaban garantizados por el valor de la vivienda (asset-based) y, como este aumentaba, tales deudores podían endeudarse más y más. Para los menos pobres, unos créditos entre los prime y los subprime, los Alt-A, permitían postergar el reembolso principal y la totalidad de los intereses durante los primeros años.

Casi con un tono fatalista, se constata que "sin embargo, la crisis llegó: a partir del primer trimestre de 2005, cayó la construcción de viviendas en Estados Unidos; en el tercer trimestre bajó el ritmo de ventas, y en el cuarto trimestre se desaceleró la subida de los precios de venta. El valor de las viviendas comenzó a descender" (Attali, 2009, p. 63). El posterior shock financiero global fue descrito, entre otros, por Zandi (2008).

Concluyendo esta retrospectiva y coronándola inevitablemente con la crisis subprime, puede afirmarse que si bien las crisis en países en desarrollo han sido recurrentes - 124 entre 1970 y 2007-, lo diferente de la crisis de 2008 respecto de tantas precedentes fue su sello made in USA. Y mientras que las otras habían sido contenidas, esta se extendió por todo el mundo, lo que no sucedía desde la Gran Depresión de los años treinta (Stiglitz, 2010).

Un paralelo en el tiempo, planteado como paradoja por uno de quienes profetizaron esta crisis, resume circularmente la visión histórica descrita: “¿Cuándo empezó la época de prosperidad?: tal vez comenzó con la repentina fiebre de la reventa de bienes inmuebles, cuando los primeros especuladores compraron y vendieron solares subdivididos como si fueran acciones de una empresa, duplicando y triplicando sus beneficios en semanas, por no decir en días (...). En un momento el auge 
se convirtió en una burbuja" (Roubini \& Mihm, 2010, pp. 29-30). Los mismos autores señalan que este relato no corresponde solo a fines de la década del 2000, sino al inicio de la Gran Depresión hace más de ochenta años: "Entonces, igual que ahora, las burbujas especulativas en el ámbito inmobiliario y bursátil, la mínima regulación financiera y la fiebre de innovación financiera conspiraron para crear una burbuja que, al estallar, sentó las bases para que el sistema financiero de Wall Street llegara al borde del colapso, se produjera una brutal depresión económica entre los ciudadanos de a pie y se generara una crisis mundial" (Roubini \& Mihm, 2020, p. 31).

Esta sintética revisión histórica de las principales crisis de los últimos siglos - sin pretensión alguna de exhaustividad- ha sido instrumental al propósito de esta investigación: relevar la evidencia de la relación entre el sector inmobiliario y las crisis económicas. La segunda sección, de índole teórica, profundizará en el análisis conceptual de esta relación, a la vez que hará mayor referencia a la crisis subprime, la más reciente y más global, iniciada -como lo indica su apodo- justamente en la burbuja inmobiliaria asociada a las hipotecas de alto riesgo o de "vivienda social".

\section{Inmobiliarización del sector financiero: aproximación conceptual}

¿Se ha vuelto obsoleto el ciclo económico? "Con buena parte del mundo en medio de la angustia de una crisis financiera y económica que recuerda la de los años treinta, estos pronunciamientos optimistas suenan casi increíblemente presuntuosos" (Krugman, 2010, p. 22). El autor responde así, dramáticamente, a quienes creían haber domesticado y superado los conocidos boom-bust cycles. A propósito de estos últimos, Laeven y Valencia (2008) identifican, solo en el período 1970-2007, 124 crisis bancarias, 208 cambiarias y 63 de deuda soberana, constatando que varios países experimentan múltiples crisis. Señalan que las crisis recientes (en 2008) en EE.UU. y Gran Bretaña no difieren significativamente de los tradicionales boombust cycles observados en las otras crisis nacionales, ya que muchos de los episodios críticos experimentan burbujas de precios, y particularmente burbujas inmobiliarias, a menudo generadas por liberalización financiera (aunque en el caso de EE.UU. no se trataría -según estos autores- de liberalización en sentido convencional, sino más bien de innovación financiera que el mercado y los reguladores no entendieron

plenamente). Para ellos, los real estate ventures han sido centrales en muchas de las recientes crisis bancarias.

Brown (2000), por su parte, ha analizado la conducta de los Real Estate Investment Trust en la declinación de los ciclos inmobiliarios. Muchas de las economías que sufrieron la última crisis presentaban vulnerabilidades similares a las de Estados Unidos, lo que no sería de extrañar, según Roubini y Mihm (2010). Estos afirman que, en primer lugar, dicho país no era ni de lejos el único con una burbuja inmobiliaria: un incremento a un ritmo inexorable en el precio de los bienes inmuebles también se había registrado en Australia, China, Dubái, España, Estonia, Irlanda, Islandia, Letonia, Lituania, Nueva Zelanda, Sudáfrica, Singapur, Tailandia y Viet- 
nam. Los mismos autores, aludiendo a The Economist, recordaban que el precio de la vivienda en EE.UU. se había incrementado en 73\% desde 1997 a 2005, más del $100 \%$ en Australia y cerca del $150 \%$ en España; y siguiendo a Colliers International, señalaban que en Dubái las casas se apreciaron en 227\% solo entre 2003 y 2007. Constataban que las razones eran las mismas: políticas monetarias laxas, inédita rebaja de los tipos hipotecarios a un solo dígito, exceso de ahorro global, menos regulación de los mercados hipotecarios y financieros, sensación de mayor poder adquisitivo de los propietarios de inmuebles de precios crecientes y, por ende, mayor gasto y menos ahorro de los mismos. En consecuencia, "el posterior boom de las inversiones residenciales elevó el PIB de muchos países” y, comparativamente y en conclusión, "la situación en Estados Unidos era mala, pero no era ni de lejos la peor, incluso aunque la burbuja inmobiliaria generara allí más préstamos problemáticos que en cualquier otro país (...). Cuando la crisis inmobiliaria atacó Estados Unidos, todas las demás economías con burbujas inmobiliarias sufrieron un declive comparable, si no mayor" (Roubini \& Mihm, 2010, pp. 210-212).

Desregulación del mercado, exceso de liquidez e intereses bajos, una burbuja inmobiliaria mundial y créditos de alto riesgo con gran incremento, junto al déficit fiscal y comercial de Estados Unidos y a una economía global desequilibrada, serían los ingredientes, según Stiglitz (2010), propicios para la crisis de 2008.

Desequilibrios previos a una crisis de consecuencias globales son reconocidos también por otros autores: "La mayor parte de Europa occidental experimentó un auge en el sector de la vivienda en los albores del siglo XXI. Los booms en el Reino Unido, Francia, España, Italia e Irlanda fueron especialmente relevantes y también ocurrieron en otros países de Europa Occidental. Sucedió lo mismo en zonas de Rusia, India, China y Corea" (Shiller, 2009, p. 9).

"A menudo se comenta que la actual crisis financiera mundial empezó en Estados Unidos. Esta afirmación no es inexacta, puesto que las primeras fisuras de la arquitectura financiera global (...) guardaban relación con las hipotecas subprime (hipotecas de alto riesgo) que se originaron en Estados Unidos. Entre enero y marzo de 2007 más de cuarenta agencias que emitieron esta clase de hipotecas en EE.UU. cerraron o se declararon en quiebra" (Shiller, 2009, p. 9).

Catalogada como la peor crisis financiera desde 1930, la de 2008, a diferencia de otras crisis periódicas asociadas a los ciclos económicos, sería el resultado de una extraordinaria expansión crediticia durante el cuarto de siglo que la precedió (Soros, 2008). Este mismo autor enfatiza que la crisis actual no es solo el estallido de la burbuja inmobiliaria norteamericana, sino el de una superburbuja -ambas vinculadas- incubada en la globalización de los mercados financieros y en una simetría que desplazó los ahorros internacionales desde la periferia, donde solía ocurrir la mayoría de las crisis, al centro. Ello permitió que Estados Unidos tuviese un déficit crónico de cuenta corriente acumulando deuda externa, mientras China y otros países acumulaban reservas externas... La crisis inmobiliaria hace caer el consumo pero también el dólar, desinflando los excesos producidos por 
las innovaciones financieras, ya que la crisis de las hipotecas subprime inducía un abombamiento de la superburbuja (Locussol, 2007).

En 2008, China, con un costo real del capital negativo, desarrolló una burbuja financiera, bursátil y un boom del mercado inmobiliario. Europa, ese mismo año, presentaba una alta probabilidad de verse tan afectada como Estados Unidos: el Reino Unido, como centro financiero, y España, con una burbuja inmobiliaria propia, parecían más vulnerables (Soros, 2008).

España desarrolló una gran burbuja en el sector vivienda, y actualmente sufre un desastre total de su mercado inmobiliario (Janoschka, 2011). El boom sectorial español -el mayor de la historia europea- respondió a una sobreabundancia de crédito que estimuló una sobreproducción de viviendas (Vergés, 2002). A diferencia de Estados Unidos, las enérgicas regulaciones bancarias españolas permitieron que sus bancos soportaran mejor la crisis, aunque el impacto de la misma en el conjunto de su economía fue mucho mayor. También el Reino Unido sufrió una burbuja inmobiliaria. Su normativa financiera flexible no funcionó mejor que la de Estados Unidos. Debido a la mayor proporción del sector financiero en la economía británica, el costo de los rescates fue, en términos relativos, mayor (Stiglitz, 2010).

La gravedad y persistencia de la crisis española requiere especial atención (García, 2008). Según Ortega y Peñalosa (2012), los desequilibrios expansivos y la reducción de los instrumentos de política económica para el ajuste fueron consecuencia de la pertenencia de España a la unión monetaria europea, coincidiendo en este diagnóstico con Bernardos (2009). Las particularidades de la crisis inmobiliaria española -incluida su burbuja propia (Colom, 2012) - y los factores de cambio de tendencia (González, 2011) son desarrollados también por Naredo (2012), quien destaca el tránsito de un modelo que priorizaba la vivienda en alquiler, tanto "libre" como social, a otro de promoción de la vivienda en propiedad. Desatada la crisis y la consiguiente recesión, el Ministerio de la Vivienda (2010) volvió a impulsar el alquiler y la vivienda "protegida", asimilando esta a un número de viviendas "libres".

Fernández-Tabales y Cruz (2013) afirman que el caso español aporta un ejemplo modélico de la interacción financiero-inmobiliaria con bajos tipos de interés (históricamente, los mínimos) e incremento significativo en los plazos medios de devolución de los préstamos hipotecarios ( 25 a 50 años). Aseveran estos autores que tales condiciones de financiación han redundado a su vez en un incremento histórico del precio de la vivienda, y ciertamente han favorecido a las empresas constructoras y agentes promotores. Las mismas condiciones favorables, a las que se agrega el ingreso de capitales extranjeros orientados a la compra de inmuebles -equivalentes a cerca del $1 \%$ del PIB español en los primeros años de la década del 2000-, fortalecieron "la concepción según la cual la vivienda se transforma de bien de uso en bien de inversión, o incluso de especulación” (Fernández-Tabales \& Cruz, 2013, p. 11).

Analizando la relación entre el alto crecimiento de la economía española previo a la crisis de 2008 y el protagonismo del sector inmobiliario en el mismo, Fernández-Tabales y Cruz (2013) señalan que es un tema muy debatido el nivel 
de influencia que haya tenido en este crecimiento "la progresiva basculación del modelo económico español hacia el sector de la construcción, pareciendo innegable que el acelerado incremento del peso proporcional del mismo no puede ser ajeno al resultado global" (p. 7). Agregan que la menor rentabilidad en otras opciones "ha contribuido de forma manifiesta a dirigir prácticamente la totalidad del ahorro nacional hacia la adquisición de suelo o inmuebles, en los que la revalorización anual por la acelerada subida de precios auspiciaba beneficios notoriamente superiores a los ofrecidos por las restantes formas de inversión" (p. 11). "La construcción se erigió, así, en la verdadera industria nacional, cuyo peso económico se elevaba bien por encima de la media europea" (Naredo, 2012, p. 65).

El rol estratégico de la economía inmobiliaria es reconocido en realidades y circunstancias muy disímiles. En Chile, un reciente Informe de Estabilidad Financiera del instituto emisor dedica una sección especial a las "implicancias" del sector inmobiliario en aquella: "El sector inmobiliario es de gran relevancia en el ciclo económico, ya sea que se considere su participación en el PIB o en la cartera de diferentes agentes financieros" (Banco Central de Chile, 2011, p. 36). Esta aseveración se ilustra, en el mismo texto oficial, al señalarse que "la participación del sector construcción y obras de ingeniería en el PIB [chileno] asciende a 6,8\% al segundo semestre de 2011. Los préstamos comerciales e hipotecarios equivalen a $38,7 \%$ del stock total de las colocaciones totales de la banca en igual período. Las compañías de seguros de vida exhiben una exposición, vía mutuos, letras y bienes inmuebles, igual al 26,1\% de sus activos totales". En el mismo texto citado se reconoce que "la importancia de los ciclos en el sector inmobiliario, así como la propagación al resto de la economía, se puso de manifiesto en la crisis subprime en EE.UU., y en la gestación de vulnerabilidades macrofinancieras en varias otras economías en el mundo, como por ejemplo Irlanda y España" (p. 36). El informe agrega: "Más aún, desde una perspectiva histórica, según Reinhart y Rogoff, las cinco crisis económicas más severas han coincidido con ciclos contractivos en este sector [inmobiliario]" (p. 36).

De acuerdo con Roubini y Mihm (2010), casi todas las crisis comienzan con una burbuja, donde el precio de un activo crece muy por sobre su valor básico subyacente, acompañado de un endeudamiento excesivo con el fin de sumarse a esa prosperidad. Otras crisis se asocian a innovaciones tecnológicas - como el ferrocarril e internet- que generan grandes expectativas. "Esa innovación tecnológica no fue el detonante de la actual crisis, impulsada por el sector inmobiliario", pero los complejos valores mobiliarios creados en los laboratorios financieros de Wall Street sí podrían dar la talla como desencadenante" (Roubini \& Mihm, 2010, p. 35). En relación con los períodos de prosperidad en los ciclos económicos y los activos de interés especulativo, señalan que "aunque el activo codiciado podría ser cualquiera, normalmente se trata de acciones de interés variable y de bienes inmuebles". Y agregan: "La reciente burbuja inmobiliaria en Estados Unidos siguió ese guion al pie de la letra: se decía que los bienes inmuebles eran una 'inversión segura', que 'nunca perdía valor' porque 'los precios de las viviendas nunca bajan"” (p. 36). El rol 
de la especulación en los ciclos inmobiliarios es ampliamente tratado por Malpezzi y Wachter (2005).

A propósito de las burbujas inmobiliarias y sus distorsiones en los mercados, De Mattos (2007) señala, siguiendo a Charmes, que "un ejemplo de esta sobreespeculación inmobiliaria es la explosión de Bangkok de 1997, origen de la crisis económica asiática $[\mathrm{y}]$ otro caso es la reciente crisis hipotecaria en Estados Unidos". Concluye el autor diciendo que "ambos casos permiten evaluar la importancia que la inversión inmobiliaria ha cobrado en la dinámica económica global en las últimas décadas" (pp. 87-88).

Con todo, y pese a la abundante evidencia histórica y a la innegable relevancia e incidencia macroeconómica del sector inmobiliario (Meen, 1996), se discute -en particular para la crisis de 2008, donde este último es especialmente protagónicoun rol causal entre una variedad de condicionantes. Roubini y Mihm (2010) afirman que la crisis de 2008 tendría orígenes estructurales, poniendo en tela de juicio la culpabilidad atribuida a las hipotecas subprime, o hipotecas basura o tóxicas, por infectar un sistema financiero global que estaba sano, pero que era de alto riesgo, con instrumentos impenetrables y opacos acompañados de un "sistema bancario en la sombra”. Los autores discrepan, asimismo, de la supuesta originalidad de la crisis, propia de las finanzas del siglo XXI, estableciendo comparaciones con las crisis anteriores. En fin, diferenciándose de otros investigadores que focalizan la crisis principal o exclusivamente en EE.UU., sostienen que se enmarca en una crisis amplia del capitalismo global del presente siglo, enfatizando que, en el capitalismo moderno, las crisis son la regla, no la excepción.

En términos diferentes pero convergentes, Shiller (2009), refiriéndose a la crisis subprime, afirma que "sin embargo no deberíamos confundir los primeros síntomas de la crisis con la causa última de la misma (...) las burbujas del mercado financiero y del mercado de valores, unos sucesos de magnitud internacional" (p. 9).

Según Roubini y Mihm (2010), una explicación habitual de la crisis refiere a la burbuja inmobiliaria, los prestatarios subprime y sus hipotecas que, titulizadas, habrían infectado y derrumbado el sistema financiero global. Estos autores sostienen que esto no fue sino el principio, y que los cambios en los gobiernos corporativos y los sistemas de bonificaciones, como también el gobierno -mediante de las políticas monetarias y las políticas a favor de la adquisición de viviendas en propiedadserían corresponsables. En cuanto a la relevancia de la intervención gubernamental, los mismos autores señalan que quedó "enana" frente a la relevancia de su inacción, a la omisión regulatoria ante el crecimiento de la banca en la sombra.

La titulización constituye uno de los cambios más importantes. En efecto, desde décadas, los bancos que realizaban préstamos hipotecarios seguían el modelo "originar para mantener", es decir, el banco que originaba la hipoteca, la conservaba. Con la innovación financiera a partir de los setenta y la titulización, "los activos elegidos como hipotecas podían ahora agruparse y transformarse en activos líquidos con los que se podría negociar en el mercado abierto (...). Con el tiempo, otros organismos gubernamentales, como Freddie Mac y Fannie Mae, entraron en 
el negocio de la titulización. También lo hicieron los bancos de inversión, las corredurías e incluso los constructores inmobiliarios (...). Distribuir los préstamos a los más capacitados para cargar con el riesgo (fondos de inversión, aseguradoras y otros inversores institucionales) podía reducir el riesgo de que se produjera una crisis financiera sistemática. La filosofía de 'originar para distribuir' sustituyó a la de 'originar para mantener'” (Roubini \& Mihm, 2010, pp. 110-112).

En relación a esto, Krugman (2010) comenta que "mientras que los precios de las viviendas siguieran subiendo, todo parecía bien y el esquema Ponzi seguía rodando. Había unas pocas hipotecas en mora, los títulos respaldados con hipotecas arrojaban grandes ganancias y los fondos continuaban entrando al mercado inmobiliario" (p. 155). El mismo economista advierte, sin embargo, que las consecuencias de la explosión de la burbuja de la vivienda fueron peores a lo imaginable: "El sistema financiero resultó ser mucho más vulnerable a los efectos colaterales de los precios de la vivienda en picada que a los efectos de la caída de la bolsa (en 2000)". "Porque el sistema financiero había cambiado de manera que nadie entendía por completo” (pp. 150 y 157). Más que la sola complejidad del sistema financiero, su alta vulnerabilidad a la caída de los valores inmobiliarios -mayor incluso al riesgo de su exposición bursátil- resulta ser una clave de significación analítica (Brueggemen \& Fisher, 2004).

Estudios de caso, como el de Reinhart y Rogoff (2011), han demostrado "que un alza desmedida en el precio de la vivienda por lo general precede a una crisis financiera" (p. 241). Entre sus secuelas, indican, "los declives en el precio real de la vivienda promedian 35\% y se extienden hasta seis años” (p. 248), y en Japón, hasta diecisiete. Recordando a Bordo y Jeanne, los mismos autores señalan que "las crisis bancarias tienden a producirse ya sea en el clímax de un boom en el precio real de la vivienda o justo después del descalabro" (p. 184). Destacan asimismo, siguiendo a Gerdrup, el vínculo entre las tres crisis bancarias de Noruega (1890 a 1993) y el ciclo de expansión y contracción en el precio de la vivienda.

Reinhart y Rogoff (2011) afirman que la "burbuja del sector inmobiliario estadounidense (...) ocupa el centro del escenario como culpable de la más reciente crisis financiera mundial. Sin embargo, la Segunda Gran Contracción (2008) está lejos de ser el único caso en este respecto. En una obra anterior documentarnos la trayectoria en los precios reales de la vivienda alrededor de todas las crisis bancarias después de la Segunda Guerra Mundial (...) en particular alrededor de las 'cinco grandes' crisis (España, 1977; Noruega, 1987; Finlandia y Suecia, 1991, y Japón 1992)” (p. 184). Las conclusiones fueron equivalentes (Reinhart \& Rogoff, 2008). Posteriormente, Harvey (2011) coincidirá en este diagnóstico, afirmando que varias de las crisis en el mundo luego de 1973 "tuvieron como base cuestiones de propiedad (raíz) o de desarrollo urbano" (p. 14), y que "no hay, por tanto, nada de original (...) en su enraizamiento en el mercado inmobiliario y en el desarrollo urbano" (p. 16). El mismo autor acentuará, en una obra posterior, "las raíces urbanas de las crisis financieras" (Harvey, 2012, p. 321). 
A la comentada mayor vulnerabilidad del sistema financiero frente a los ciclos inmobiliarios se agrega, según varios autores, el también mayor efecto riqueza de la vivienda. Tanto este último como el factor de riesgo asociado a la exposición inmobiliaria directa o indirecta ayudan a comprender cómo los ciclos inmobiliarios detonan las crisis bancarias.

De acuerdo con Stephanie Pomboy, y en particular con Robert Shiller, los autores Foster y Magdoff (2009) destacan que el efecto riqueza de la vivienda puede ser mayor que el del mercado bursátil y que, como lo ha demostrado Shiller, la vivienda tiene el doble de correlación con el consumo que el mercado bursátil. De aquí que la "burbuja inmobiliaria y la fortaleza del consumo en la economía están conectadas con lo que podría denominarse 'la burbuja del endeudamiento de los hogares', que podría estallar fácilmente si los tipos de interés aumentan y el precio de la vivienda se estanca o desciende" (Foster \& Magdoff, 2009, p. 54). La alta correlación vivienda-consumo, intermediada por el crédito, evidencia el rol articulador del sector inmobiliario entre el sistema financiero y la economía real.

Consecuentemente con las argumentaciones expuestas, "puede conjeturarse que una de las razones por las que las grandes crisis bancarias tienden a prolongarse por tanto tiempo es que estos episodios involucran el persistente ciclo del sector inmobiliario (...). Luego de la reciente crisis hipotecaria, la contracción del sector financiero durante 2008-2009 acabó siendo considerablemente más grande” (Reinhart \& Rogoff, 2011, pp. 186-187).

Si efectivamente hay una cierta relación de causalidad entre los ciclos inmobiliarios y las crisis financieras, entonces no puede sorprender que, identificando "los indicadores de alerta temprana de una crisis", Reinhart y Rogoff (2011) describan que "en el caso de las crisis bancarias el precio real de la vivienda ocupa casi el primer sitio en la lista de indicadores confiables (...) pues es el que produce un menor número de falsas alarmas. Monitorear la evolución del precio de la vivienda tiene entonces un evidente valor añadido al tratar de predecir potenciales escenarios de crisis bancaria" (pp. 300-301).

El rol económico excepcionalmente determinante del sector inmobiliario justifica que se pueda afirmar que "los Estados Unidos, Gran Bretaña, España y varios otros países probablemente hubieran sufrido recesiones cuando sus burbujas inmobiliarias reventaron, aun si el sistema financiero no se hubiera derrumbado" (Krugman, 2010, p. 185). Explica el autor que ello habría ocurrido por el efecto negativo en el empleo con la caída de la construcción y la consiguiente reducción del gasto -ya que los consumidores pierden acceso a préstamos sobre el valor de sus casas y se sienten más pobres-, lo que a su vez tiene un efecto multiplicador con menos empleo y menos gasto.

Aislando el sector inmobiliario del financiero en un escenario de crisis, Paul Krugman ratifica la relevante incidencia del primero como generador, por sí mismo, de recesiones económicas. Concuerdan en esta aseveración Reinhart y Rogoff (2011), al señalar que "es importante destacar, sin embargo, que de acuerdo con la teoría sobre crisis bancarias (...), estas son más un mecanismo de amplificación y no 
necesariamente un mecanismo causal (...). Los colapsos del sector inmobiliario y en el precio de las acciones asociados con una crisis bancaria tendrían efectos negativos de consideración incluso en la ausencia de un derrumbe bancario" (p. 198).

Las crisis bancarias son un mecanismo de amplificación y de contagio -más aún, un medio de la financiarización- antes que un factor de causalidad. La vulnerabilidad del sector financiero frente al ciclo inmobiliario y los efectos multiplicadores de aquel fueron previstos y anunciados por Roubini: en septiembre de 2006 anticipó el estallido de la burbuja inmobiliaria, señalando que el impago de las hipotecas paralizaría todo el sistema financiero global al revelarse valores con respaldo hipotecario por billones de dólares, con consecuencias en todo el sistema financiero, desencadenando una crisis. Predijo que esta no tardaría en propagarse al exterior generando una pandemia financiera global (Roubini \& Mihm, 2010). La burbuja había sido detectada tres años antes por Case y Shiller (2003), en su etapa de inflación inicial.

\section{Indicadores macroeconómicos inmobiliarios: aproximación cuantitativa}

"Al comienzo de la crisis no sucedía aparentemente nada fuera de lo común, excepto la incapacidad de un grupo de familias norteamericanas para reembolsar sus créditos inmobiliarios (...) y de pronto nos vemos confrontados, sin previo aviso, a los inicios de una depresión mundial, la más grave en los últimos ochenta años" (Attali, 2009, p. 9). Con un tono de perplejidad, este autor afirma en el mismo texto: "Muy pocos expertos advertían que la deuda privada y no la pública era la que generaría los problemas. Casi ninguno de ellos comprendía que la crisis se desataría a causa de las deudas inmobiliarias de los hogares más pobres" (p. 59).

La Reserva Federal -luego de la explosión de la burbuja tecnológica de las punto com en 2000 y el $11 / S$ de 2001 - bajó y mantuvo su tasa al $1 \%$ hasta mediados de 2004, permitiendo que se forjara una burbuja financiera e inmobiliaria en los Estados Unidos. La diferencia de esta burbuja inmobiliaria respecto de otras en diversos países "era su tamaño e importancia para la economía global y el sistema financiero internacional (...) había valores hipotecarios de Estados Unidos distribuidos por todo el mundo" (Soros, 2008, p. 125).

Aun considerando el volumen de esta burbuja y su trascendencia internacional, cabe preguntarse: ¿cómo una crisis inmobiliaria circunscrita a Estados Unidos deviene en una crisis mundial? Ramonet (2009) plantea esta cuestión y afirma que la desregulación bancaria y la hipersofisticación de la industria y la ingeniería financieras explican, preferentemente vía la titularización -entre muchos nuevos instrumentos-, dicha propagación. La "titularización”, iniciada en la década de los ochenta, transforma préstamos bancarios inmobiliarios en activos financieros transables en los mercados. Esta es, sin duda alguna, más una revolución para la economía inmobiliaria que para los mercados financieros.

En relación con este proceso de financiarización, Corpataux, Crevoisier y Theurillat (2009) plantean que para pasar desde el capital real (edificios, 
infraestructura...) al capital financiero, se requieren ciertas transformaciones; en primer lugar e imperativamente, que el control del capital real sea formalizado mediante de su securitización (equity and shares); un contexto institucional y legal que incentive su movilidad y rentabilidad; tecnologías informáticas y telecomunicaciones; y agentes e instituciones de intermediación especializada. Los autores citados definen financiarización, consecuentemente, como la construcción progresiva de movilidad/liquidez del capital de las firmas, sectores, regiones y naciones gracias a los mercados financieros.

Una de las consecuencias, entre otras, de la financiarización descrita fue que los excedentes de ahorro de Japón, Alemania, China, y de varias economías emergentes, se invirtieran comprando la deuda de Freddie Mac y Fannie Mae y otros valores, con respaldo hipotecario garantizado por tales instituciones: "Todos estaban implícitamente garantizados por el Tesoro de Estados Unidos" (Roubini \& Mihm, 2010, p. 139). Estos autores agregan que los acreedores privados de ese país, en especial inversores e instituciones financieras de Europa, fueron los mayores compradores de productos titulizados, impulsando la creación de la burbuja inmobiliaria.

La burbuja hizo crisis en 2006 por el incremento de los tipos de interés, lo cual causó un cambio en la dirección de los precios de la vivienda (Foster \& Magdoff, 2009). "La crisis (subprime) instantáneamente afectó a los agentes financieros de Europa y Asia. Sin embargo, se demoró cerca de un año en transmitir el shock a la economía real, lo que muestra la relativa independencia de los dos ámbitos" (Corpataux, Crevoisier \& Theurillat, 2009, p. 330). Cuando la burbuja se rompió, los propietarios debían más por sus hipotecas de lo que se valoraban sus casas. Las tasas medias de ahorro habían caído a cero. La explosión afectó primero a las hipotecas de alto riesgo de familias de ingresos bajos - perdieron sus hogares, sus ahorros, sus opciones de educación universitaria-. Luego se expandió a toda la propiedad inmobiliaria residencial, y enseguida comercial. Cayó la demanda, el valor de las acciones, la posibilidad de endeudamiento, y luego colapsó la industria manufacturera norteamericana... Los efectos se amplificaron porque los bancos inventaron productos complejos de base hipotecaria que multiplicaban el riesgo y engañaban a los entes reguladores, los que se habían dispersado en el sistema bancario mundial. Sin la seguridad y la confianza que los sustentan, los mercados mundiales de crédito se desmoronaron (Stiglitz, 2010).

Según Foster y Magdoff (2009), la aceleración del endeudamiento de las familias fue secundada de manera importante por la Reserva Federal al reducir los intereses a niveles extremadamente bajos, para evitar una recesión luego de la inflación bursátil en 2000. Estos autores señalaban que entre ese año y 2005 el endeudamiento hipotecario de los hogares subió en $75 \%$, a medida que los propietarios de viviendas obtenían hipotecas mayores y extraían dinero de ellas para diversos fines. Esto incentivó la economía, y la inversión en vivienda privada se incrementó hasta el 36\% de la inversión privada total en 2005, un nivel no registrado desde el auge de las urbanizaciones ligadas al automóvil en 1958. 
Reinhart y Rogoff (2011), de acuerdo con Philippon, expresan que "la titularización permitió que los consumidores estadounidenses transformaran activos inmobiliarios tradicionalmente ilíquidos en cajeros automáticos, lo que significó una reducción en el ahorro" (p. 234).

Según Cassidy (2011), la Reserva Federal, conservando su tasa en menos del $2,5 \%$ desde fines de 2001 a principios de 2005, hizo bajar la mayoría de las demás tasas a niveles casi inéditos, con una farra de endeudamiento de los compradores de inmuebles y comerciantes, consumidores y especuladores como resultado: desde fines de 2002 a fines de 2006, la suma total de deudas vigentes en EE.UU. subió más del $42 \%$. Ese solo incremento equivale a 43.000 dólares por habitante o a 128.000 dólares por hogar.

En el marco del creciente endeudamiento de los hogares, el incremento acelerado de los préstamos garantizados con vivienda es de máxima relevancia macroeconómica. Citando cifras del Financial Market Center para el último trimestre de 2005, Foster y Magdoff (2009) ilustran dicha cuestión señalando que en ese periodo el incremento de préstamos hipotecarios creció en más de 1 billón de dólares, con lo que la deuda hipotecaria pendiente de pago se elevó a más de 8,6 billones, cerca del 70\% del PIB de los Estados Unidos. "Mientras que en 1981 la deuda del sector privado de Estados Unidos equivalía al ciento veintitrés por ciento del Producto Interior Bruto (PIB), a finales del año 2008 se había disparado hasta el doscientos noventa por ciento (...). La deuda de los hogares suponía el cuarenta y ocho por ciento del PIB en 1981, pero en el año 2007 había aumentado hasta el ciento por ciento" (Roubini \& Mihm, 2010, p. 141). Estos autores explican que gran parte de esa deuda devino como apalancamiento en el sector inmobiliario, ya que se compraban viviendas cada vez más caras con cada vez menos capital.

Marichal (2010), refiriéndose a las causas internas de la expansión de los mercados financieros estadounidenses -y siguiendo a T. Phillippon- afirma que "en el caso del período de 1996 a 2006, este crecimiento estaba ligado en particular a la fortísima expansión de la industria de la construcción y el negocio hipotecario"(p.286). El mismo autor indica que, a partir de 2001, el crédito barato motivó el mayor auge en el mercado de la vivienda en la historia norteamericana, señalando que el monto total de hipotecas, que equivalía a 2,5 billones de dólares a mediados de los noventa, alcanzó a casi 10, 4 billones en 2007. Concluye que la maquinaria entrelazada y configurada por la industria de la construcción de viviendas, los bancos y las firmas financieras promovió un crecimiento desmesurado del sector inmobiliario e hipotecario.

En este contexto de gran incidencia macroeconómica del sector inmobiliario y de sus efectos multisectoriales, Soros (2008) enfatiza que en el sexenio previo a 2008 las familias norteamericanas acumulaban más créditos hipotecarios que en toda la historia del mercado de hipotecas. Los préstamos por dicho concepto alcanzaron a más de 11.000 millones de dólares en 2007, duplicando el valor de 2001. En 2006, las hipotecas de alto riesgo (subprime) y de medio riesgo (Alt-A) representaban el 33\% de las hipotecas nuevas: las primeras pasaron del 7 al 20\% entre 2001 y 
2006, y las segundas del 2 al 12\% en igual período. El precio real de las casas subía en paralelo cerca del 50\%, mientras que la deuda del mercado de crédito llegaba a representar cerca del 350\% del PIB de los Estados Unidos, su nivel más alto en más de cincuenta años. En particular, los créditos con garantía hipotecaria llegaron a cerca de un billón de dólares en 2006: 8\% del PIB y más que el déficit por cuenta corriente (Soros, 2008).

Attali (2009) sintetiza la situación indicando que "en 2007 los norteamericanos acumulaban 900.000 millones de deuda privada en sus tarjetas de crédito, el doble en comparación con la década anterior. La deuda de los hogares (...) pasó del 46\% del PIB en 1979 al 98\% en diciembre de 2007". A su vez, agrega, "la deuda externa norteamericana superó los $7 \mathrm{~T}$ (siete billones de dólares), es decir, el 70\% del PIB (...). La deuda total de los norteamericanos (incluyendo todos los agentes) llegaba al 350\% del PIB en diciembre de 2007, más que en 1929" (pp. 57-58). Señala que el monto total de los títulos -fueran o no inmobiliarios- alcanzó los 12 T (12 billones de dólares), suma equivalente a los bonos del Tesoro norteamericano. El dinero barato causó así una burbuja inmobiliaria: entre 2000 y 2005, el valor de las viviendas subió más del $50 \%$ junto a un boom de nuevas construcciones. Merrill Lynch observaba que casi la mitad del crecimiento del producto de Estados Unidos en el primer semestre de 2005 estaba relacionado directa o indirectamente -por el dinero generado por la refinanciación hipotecaria- con las viviendas. El pronunciado crecimiento del precio de la vivienda llevó a la especulación. Ese año, según Mason y Rosner, el $40 \%$ de las viviendas adquiridas tenía como finalidad la inversión o servir de segunda vivienda (Soros, 2008).

Que la mitad del crecimiento del producto de la economía más importante del mundo -y una ciertamente muy diversificada- esté, aunque sea temporalmente y aunque no siempre de modo directo, relacionada con el sector vivienda, es un indicador suficientemente elocuente de su trascendencia macroeconómica y de la compleja y múltiple matriz intersectorial de la propia economía inmobiliaria. Esta misma condición cualitativa e incidencia cuantitativa permiten comprender la magnitud y gravedad de la crisis. De otro modo resultaría inexplicable.

Una situación similar -guardando todas las diferencias- fue experimentada, en auge y caída, por la economía española, incluso sin la complicidad protagónica de los derivados financieros ni la crisis bancaria observables en los Estados Unidos (aunque en los años siguientes las cajas y la banca españolas comenzaron a acusar un efecto retardado de sus compromisos hipotecarios).

"España representa un caso excepcional a nivel mundial del crecimiento del sector de la construcción y subsector de la vivienda desde los últimos años del siglo pasado hasta 2007, a partir del cual el sector se paraliza y arrastra al conjunto de la economía española" (Fernández-Tabales \& Cruz, 2013, p. 5). Estos autores explican que, en el contexto del ciclo expansivo de la economía española desde mediados de los noventa hasta 2007 -superior al de la Unión Europea de los 12 de Maastricht-, la construcción incrementa su Valor Añadido Bruto (VAB) en la economía nacional en $43 \%$ entre 2000 y 2007, el más acusado crecimiento 
basado principalmente en viviendas nuevas: 18.000 por cada millón de habitantes frente a 5.000 por millón en los mercados de la Unión Europea. En contraste, el descenso de las estadísticas luego del cambio de tendencia en 2007 es muy brusco: el número de viviendas libres iniciadas en 2010 no alcanzó al 10\% de la cifra de 2006, según los mismos autores, y las ventas de viviendas cayeron en casi $48 \%$ entre 2007 y 2009; a fines de 2008 había en España cerca de un millón de viviendas vacías no vendidas.

La cuantía macroeconómica del sector inmobiliario y su impacto recesivo en tiempos de crisis fueron también evidentes en el caso japonés, de la mano de la caída del mercado de valores. Ramonet (2009) ilustra -con cifras de Le Nouvel Observateur de 2008- cómo la deflación desplomó la bolsa de Tokio y los precios del sector inmobiliario cayeron en 70\%: las pérdidas de activos inmobiliarios y bursátiles se aproximaron a los 7 billones de euros entre 1990 y la crisis de 1997, equivalentes a 24 puntos del PIB japonés.

Tres casos distintos - en Asia, Europa y América- demuestran de modo contundente la significación macroeconómica del sector inmobiliario y su efecto multiplicador en períodos de crecimiento y de recesión. No es casual que economistas tan reconocidos como Stiglitz (2010) y Shiller (2009:121) afirmen, el primero, que entre dos tercios y tres cuartos de la economía estadounidense estaban relacionados con la vivienda (¡superando la apreciación de Merril Lynch!), mientras que el segundo, complementariamente, que "el mercado inmobiliario es uno de los activos más importantes, comparable en tamaño a todo el mercado de valores".

Ramonet (2009), aludiendo a Hervé de Carmoy, señala que el total de la riqueza producida anualmente en la economía global es de aproximadamente 50 billones de euros, y que el valor del stock mundial de los bienes inmobiliarios es del orden de 75 billones. Resalta, sin embargo, que a fines de 2007 , el valor total de los productos derivados superaba los 1.000 billones de euros.

Otros autores destacan la acentuada influencia de la economía inmobiliaria aunque con intermediación financiera- en el empleo, el gasto y la inversión: "desde el colapso del mercado de las hipotecas de alto riesgo (subprime) en julio de 2007, el pánico y los problemas financieros se extendieron (...) infectando a todos los sectores uno tras otro (...). Este lío financiero no tardó en registrarse con números negativos en la economía 'real': caída del empleo, debilitamiento del consumo y la inversión, y disminución de la producción y los beneficios" (Foster \& Magdoff, 2009, p. 132). La inestabilidad pasó de las viviendas a la deuda de las tarjetas de crédito, a los créditos para locales comerciales y automóviles, e incluso a los bonos municipales, por medio de las aseguradoras contaminadas por productos sintéticos y estructurados de nueva creación (Soros, 2008).

"Este lío financiero" fue de tal magnitud que en Estados Unidos los avales y rescates gubernamentales se acercaron al 80\% del PIB, unos 12 billones de dólares. Pero además se otorgaron cientos de miles de millones de dólares como pagos encubiertos. La Reserva Federal compró hipotecas asumiendo garantías de poca 
calidad; los préstamos a los bancos se hicieron con un interés cercanos a cero (Stiglitz, 2010).

Proporcionales a la gran influencia económica y financiera del sector inmobiliario son también sus efectos: la burbuja inmobiliaria fue tan importante para contrarrestar el estancamiento económico y como base de la financiarización, y también para el bienestar de los hogares norteamericanos, que la debilidad del mercado inmobiliario podría llevar a una contracción económica y a un caos financiero generalizado (Foster \& Magdoff, 2009). Los mismos autores concluyen que, debido a que el consumo en EE.UU. es la principal base de la demanda de la economía mundial, se hace más probable una crisis global. "La crisis de las subprime tampoco terminó en las fronteras de Estados Unidos. Los boyantes mercados inmobiliarios han dado señales de debilidad, o al menos de estancamiento, en muchos países" (Shiller, 2009, p. 18). Wolff (2006) había hecho poco antes una revisión internacional de los activos inmobiliarios, en la víspera de la crisis.

La crisis se hizo global con celeridad, ya que casi un cuarto de las hipotecas estadounidenses se había dispersado, para beneficio relativo de ese país, en el extranjero. Al final, Estados Unidos también exportó su recesión (Stiglitz, 2010; Jorión, 2008). Para Marichal (2010), "la crisis contagió a América Latina luego del segundo semestre de 2008 a través de un descenso en las exportaciones, la reducción de los flujos de inversión extranjera directa, las remesas decrecientes y una caída significativa del turismo internacional" (p. 312).

Entre los efectos y consecuencias de la crisis, Agosín (2010) destaca el gran aumento en las primas de riesgo para las economías emergentes. Ejemplifica, en el caso de Chile, con el incremento de 80 a 350 puntos básicos en los papeles soberanos entre 2007 y 2008. En Chile, Muga (2010) destaca que la construcción, junto a la industria, resultó ser el sector más afectado por la crisis internacional: el número de ocupados en 2009 era 8,4\% menor que el del año anterior y la tasa de desempleo sectorial alcanzó al 18,5\%; las solicitudes de permisos de edificación cayeron en más de $60 \%$ en 2009 respecto de 2008; y el número de meses necesarios para agotar el stock se incrementó hasta 17 en julio de 2009; en fin, la inversión total en vivienda cayó ese año en más de $22 \%$. Las exportaciones chilenas decrecieron, en su variación anualizada, hasta $41 \%$ en el primer trimestre de 2009. Buena parte de esta caída se asocia a la baja del precio del cobre (Moyano, 2010).

Pero, como se sabe, los efectos transnacionales de la crisis afectaron también a las economías desarrolladas: desde mediados de 2008 a mediados de 2009 las exportaciones japonesas cayeron en más de un tercio, y las de Alemania en casi una cuarta parte (Stiglitz, 2010).

Entre los múltiples impactos de la crisis, que dan cuenta reiterada de la marcada incidencia inmobiliaria en tantos y variados sectores económicos, algunos estudios relevan sus consecuencias en los presupuestos subnacionales. Arezki y Sy (2011) plantean que las crisis inmobiliaria y financiera, además de la recesión, impactaron los ingresos impositivos de los gobiernos estatales y locales en Estados Unidos y produjeron señales de inestabilidad. Indican estos autores que para los 
inversionistas en bonos municipales y estatales hay una distinción de importancia, ya que, a diferencia del marco normativo previsto para las municipalidades, no existe un régimen de quiebra en el caso de los estados, pudiendo estos repudiar su deuda y, sin espacios para efectuar ahorros -situación agravada por mayores ajustes en el presupuesto federal-, los estados reducirían los fondos para sus ciudades y condados. Al disminuir el valor y las plusvalías inmobiliarias, también se reducen los ingresos por impuestos. Los estados y las localidades, cuyo gasto constituye casi una tercera parte de todo el gasto gubernamental, ven afectados sus presupuestos. En 2009, tan solo California tuvo que disminuir gastos y subir impuestos por 42.000 millones de dólares (Stiglitz, 2010).

En el caso español, Fernández-Tabales y Cruz (2013) destacan la proporción que corresponde a la recaudación del Impuesto de Bienes Inmuebles (IBI) de naturaleza urbana en el total de los presupuestos municipales, revelando el grado de dependencia que las haciendas locales, en especial en el litoral, tienen respecto de la tributación inmobiliaria.

Pero estos efectos locales no son sino expresiones específicas del contagio de una crisis global detonada por el sector inmobiliario a partir de la hipotecas subpri$m e$. ¿Por qué? Debido al enorme tamaño de la burbuja inmobiliaria. Nacionalmente, para el verano de 2006 la vivienda estaba sobrevalorada quizá en más del 50\% y, "a la hora del juicio financiero final, la terminación de la burbuja de la vivienda había eliminado 8 billones [de dólares] de riqueza” (Krugman, 2010, pp. 174-175).

En enero de 2008, según Ramonet (2009), el valor total de ocho grandes bolsas -de Nueva York, Tokio y seis ciudades de Europa occidental-alcanzaba a 23,5 billones de euros: diez meses después se reducía a la mitad.

Estimaciones con datos de la Organización para la Cooperación y el Desarrollo Económico (OCDE), de la World Stock Exchange Federation y del Fondo Monetario Internacional (FMI) llevan a Moyano (2010) a inferir que el total de pérdida de riqueza global, a octubre de 2009, "sería del orden de US\$ 77 mil millones de millones, es decir, alrededor de 140\% del PIB mundial” (p. 137).

No casualmente, un estudio del Fondo Monetario Internacional (Laeven \& Valencia, 2008) sobre 127 crisis económicas acaecidas en las tres últimas décadas en una treintena de países - citado también por Ramonet (2009, p. 22) - "confirma que las que nacen a partir de los sectores inmobiliario y bancario son particularmente 'intensas, largas, profundas y nocivas para la economía real'”(iqué duda cabe!). Shiller (2009) lo confirmaba tempranamente: "la crisis de las subprime es la denominación de un punto culminante e histórico de nuestro sistema económico y nuestra cultura. Se ha producido fundamentalmente tras el estallido de una burbuja en el mercado inmobiliario que empezó en Estados Unidos en el año 2006 y ya ha causado estragos en muchos otros países a modo de derrumbes financieros y crisis de liquidez global en los créditos” (p. 13). Su pronóstico resultaría dramáticamente profético: "Es probable que hayamos entrado en una grave recesión económica que causará problemas para millones de personas, propagándose más allá de las hipotecas subprime que se sitúan en el epicentro de esta crisis" (Shiller, 2009, pp. 17-18). 


\section{Conclusiones}

1. Los ciclos de precios de la vivienda, y más ampliamente del sector inmobiliario, han estado estrecha y recurrentemente relacionados con las crisis bancarias y financieras (Laeven \& Valencia, 2008; Roubini \& Mihm, 2010; Reinhart \& Rogoff, 2011). Desde el siglo XIX al menos, y tanto en países desarrollados como emergentes de los diversos continentes, se verifica dicha relación (Marichal, 2010; Roubini \& Mihm, 2010). Históricamente, esta precede con mucho a los procesos más recientes de bancarización generalizada y financiarización. Estos últimos, y más específicamente la titularización y otros derivados, lejos de causar por sí mismos las crisis, actúan más bien como instrumentos de multiplicación y contagio (Stiglitz, 2010). El factor inmobiliario ha sido el detonante de las crisis más severas posteriores a la Segunda Guerra Mundial (Ramonet, 2009; Reinhart \& Rogoff, 2011; Harvey, 2011), aunque también precedió a la Gran Depresión (Attali, 2009; Shiller, 2009) y, últimamente, a la crisis subprime con todas sus secuelas.

2. La creciente movilidad geográfica de capitales (Soros, 2008; Krugman, 2010; Reinhart \& Rogoff, 2011) a escala global se ha demostrado como una de las causas que, con cierta regularidad y en conjunto con otras endógenas, incrementa la disponibilidad de créditos con intereses menores, el endeudamiento, el consumo y la especulación, con un efecto precio en los activos, sobre todo con los inmobiliarios y bursátiles (Roubini \& Mihm, 2010). Los ciclos y burbujas en los respectivos mercados, de manera más o menos simultánea o secuencial, han sido la consecuencia más clara y constante de tales procesos. La crisis del sudeste asiático y más actualmente la de los Estados Unidos y España, entre otras, ilustran la vinculación de sus burbujas inmobiliarias con el ingreso de capitales externos, sumado a otros factores crediticios locales (Shiller, 2009; Bernardos, 2009; Roubini \& Mihm, 2010; Stiglitz, 2010; González, 2011; Colom, 2012; Ortega \& Peñalosa, 2012).

3. La titulización, ampliando casi ilimitadamente la transabilidad hipotecaria (Ramonet, 2009; Roubini \& Mihm, 2010) y, por ende, la liquidez de activos natural o tradicionalmente poco líquidos y de altos costos de transacción, constituyó, más que una sola innovación de ingeniería financiera, una verdadera revolución inmobiliaria. Convirtiendo capitales reales en capitales financieros (Corpataux, Crevoisier \& Theurillat, 2009), la titulización permitió de modo radical la financiarización del sector inmobiliario, otorgando amplia movilidad a activos casi por definición inmóviles. Ello no solo hizo posible una mayor participación hipotecaria en las colocaciones de los fondos de inversión, de pensiones y de seguros, sino que también permitió un mayor endeudamiento hipotecario, multiplicando la deuda de los hogares y del sector privado en 
general. La titulización, incrementando su transabilidad y liquidez, financiarizó al sector inmobiliario a la vez que "inmobiliarizó" al sector financiero.

4. Este último ha acusado demostrada y recurrentemente una mayor vulnerabilidad a los ciclos de precios de la vivienda y a las burbujas inmobiliarias que a las bursátiles (Krugman, 2010). De un lado, el efecto precio del crédito es mayor en la vivienda (Roubini \& Mihm, 2010). En extremo, produce un "efecto burbuja”. De otro lado, la vivienda -más aún sobrevaluada- genera un mayor efecto riqueza y, consecuentemente, una más alta correlación con el endeudamiento y el consumo (Foster \& Magdoff, 2009; Roubini \& Mihm, 2010). La titulización, a su vez, fragmentando, atomizando y dispersando el riesgo hipotecario (Roubini \& Mihm, 2010; Stiglitz, 2010), lo minimiza para algunos y lo endosa e incrementa para muchos, potenciando un efecto contagio inconmensurable. Sin causar las crisis por sí misma, la titulización las maximiza. Cuando la deuda hipotecaria llega a ser casi equivalente al PIB de la mayor economía mundial (Foster \& Magdoff, 2009); cuando los créditos con garantía hipotecaria llegan a ser mayores a su déficit en cuenta corriente (Soros, 2008); y cuando el monto total de títulos, incluidos los inmobiliarios, es comparable al de los bonos del Tesoro de los EE.UU. (Attali, 2009), entonces es más comprensible la mayor vulnerabilidad del sector financiero frente a los ciclos y burbujas del sector inmobiliario y, más aún, la mayor severidad, gravedad y duración de las crisis detonadas por él.

5. La relevancia macroeconómica de la economía inmobiliaria da más razón a las conclusiones anteriores. Por su alta contribución al PIB, por su decidida participación en la inversión, por su amplio impacto en el empleo y en el gasto además de los significativos efectos e índices financieros ya referidos-, el sector inmobiliario tiene un peso macroeconómico y estratégico superior. En efecto, si, como aconteció en la década pasada en la mayor economía, la inversión privada en vivienda llegó a representar más de un tercio de la inversión privada total (Foster \& Magdoff, 2009); si el sector vivienda dio cuenta, al menos en un semestre, del 50\% del incremento del PIB (Soros, 2008); y si entre dos tercios y tres cuartas partes de la diversificada economía estadounidense estaban relacionados con la vivienda (Stiglitz, 2010), entonces no cabe duda alguna de la determinante incidencia macroeconómica del sector inmobiliario. ¿Podría el sector financiero ser poco vulnerable, incluso sin la titulización, a tamaña realidad? ¿Podrían las crisis bancarias, antes y después de la titulización, no estar relacionadas con los ciclos inmobiliarios? En fin, ¿podrían ser tales crisis menos agudas, más breves y menos graves que lo que han resultado ser?

6. La incidencia macroeconómica del sector inmobiliario hizo y hace posible, en períodos de expansión del ciclo de inversiones y precios de la vivienda, un incremento mayor del PIB (Roubini \& Mihm, 2010), tal como se ha registrado 
en diversas economías y, más recientemente, en EE.UU. y España, entre otros países. La alta ponderación del sector de la construcción en el producto durante un período de varios años, en el caso español (Vergés, 2002; FernándezTabales \& Cruz, 2013; Janoschka, 2011; Naredo, 2012) y la expansión del crédito, sobre todo hipotecario, luego de la crisis bursátil de las punto com y como compensación incentivadora de la economía estadounidense en el primer lustro de los años 2000 (Attali, 2009; Foster \& Magdoff, 2009; Roubini \& Mihm, 2010; Cassidy, 2011), demuestran que el gran efecto macroeconómico de la economía inmobiliaria puede producirse vía mercado e inducirse vía políticas públicas, para prevenir o mitigar recesiones o francamente como medio de aceleración económica. Todo lo anteriormente expuesto -en este punto y los precedentes- hace inteligible el proceso contrario; es decir, el enorme potencial del sector inmobiliario para producir, por sí mismo, recesiones económicas, incluso sin la concurrencia de derrumbes bancarios o financieros (Krugman, 2010), con el agravante de que sus ciclos recesivos prácticamente duplican en duración a los bursátiles (Reinhart $\&$ Rogoff, 2011) y suelen tener un mayor impacto financiero en la inversión, el empleo y el consumo.

7. El estratégico rol articulador del sector inmobiliario entre la economía real y la financiera, debido a su peso macroeconómico y sus vastas y complejas relaciones multisectoriales, determina que -como se ha expuesto- tal sector esté estrictamente relacionado con las más importantes crisis bancarias y financieras. En consecuencia, "las conexiones entre urbanización, acumulación del capital y formación de crisis merecen analizarse cuidadosamente" (Harvey, 2011, p. 137). Las crisis financieras, más que constituirse en la causa originaria de las recesiones, las amplifican (Reinhart \& Rogoff, 2011) y contagian, ciertamente con mayor potencia y celeridad luego de la titulización y financiarización inmobiliarias. Por lo mismo, los precios de la vivienda pueden constituirse en los primeros y más asertivos indicadores de alerta temprana de las crisis bancarias (Reinhart \& Rogoff, 2011), confirmando tanto el rol detonante de las mismas desempeñado por los ciclos y burbujas inmobiliarias, cuanto la mayor vulnerabilidad del sector financiero a tales ciclos.

Las "raíces urbanas de las crisis financieras" (Harvey, 2012, p. 321) y la relación entre los ciclos inmobiliarios y las crisis económicas se fundamentan, estructuralmente, en la creciente urbanización de la población y la economía. Golub (2010) constata que en 2007-2008 la población urbana superó por primera vez a la población rural a nivel mundial; que más de 3.300 millones de personas viven en ciudades y que, de ellas, más de 500 millones lo hacen en megalópolis y ciudades de más de 5 millones de habitantes. Recordando a Mumford, afirma que el mundo entero se ha convertido en una ciudad, en una constelación de polos urbanos que son los nodos del espacio económico globalizado: "las capitales del capitalismo". 
A la urbanización creciente de la economía se suma una progresiva concentración y metropolización de los sectores inmobiliario y financiero, y ciertamente también del poder político y, por ende, de la regulación -o desregulación- de tales sectores y de su producción urbana. La yuxtaposición de esta doble concentración, económica y territorial, se expresa en una verdadera "metromonopolización" financiero-inmobiliaria.

Junio de 2012. Al concluir la redacción de este texto -casi cuatro años después del estallido de la crisis subprime-, el problema de las hipotecas inmobiliarias en los Estados Unidos sigue sin resolverse, y la crisis no está superada. En España, los bancos y cajas de ahorro aún tienen pendiente el saneamiento de sus activos inmobiliarios, "liquidan" las viviendas en sus carteras o las traspasan a terceras sociedades, y hacen provisiones en sus balances por préstamos de propiedades impagas; a las ejecuciones hipotecarias se suma cerca de un millón de casas sin vender. En Estados Unidos, millones de familias perdieron sus casas, surgiendo así, según McKinley (Cohen, 2012), "ciudades carpas" o hoovervilles. La Administración Federal de Viviendas estadounidense enfrenta problemas similares a los señalados anteriormente, y el Centro Nacional de Familias Sin Techo debe asistir a millones que deambulan en las calles. En Europa, la crisis incrementó las migraciones al punto de plantearse la opción del cierre de fronteras, contraviniendo el acuerdo de Schengen: surgieron o se fortalecieron los nacionalismos y las reivindicaciones de autonomías, y el movimiento de los "indignados" -Movimiento $15 \mathrm{M}$ en la Puerta del Sol en Madrid- se replicó en más de ochenta países, incluso en los Estados Unidos $(O c$ cupy Wall Street en el Parque Zuccotti). En este país, en una verdadera paradoja, la pobreza llega al 16\% de la población (casi cincuenta millones de personas), proporción que supera la de muchos países emergentes. El desempleo alcanza al 11\% en la Unión Europea y a más del 24\% en España. Las secuelas de la crisis subprime, sumadas a crisis inmobiliarias y fiscales y recesiones en varios países europeos, han detonado cambios políticos y de gobiernos más o menos drásticos en Irlanda, España, Grecia, Italia, Francia. La eurozona arriesga un quiebre al mismo tiempo que intenta una unión fiscal. Curiosamente, países tan distintos como Grecia y Estados Unidos intentan poner en venta o arriendo miles de propiedades públicas para incrementar sus ingresos fiscales y servir sus abultadas deudas. El precario crecimiento de la economía estadounidense y la recesión más o menos generalizada entre los países europeos han influido en las recientes contracciones de las economías de China y Brasil, las que presentaban, además, signos de burbujas inmobiliarias. La volatilidad de las principales bolsas de los Estados Unidos -y su influencia sobre las del resto del mundo- responde sensiblemente, entre otras variables, a los índices de construcción y ventas de viviendas... Es la historia aún inconclusa de la vivienda social estadounidense que, financiarizada, inmobiliarizó al sector financiero y desfinanciarizó la banca internacional, en una crisis global con dramáticas consecuencias sociales y políticas. @EURE 


\section{Referencias bibliográficas}

Agosín, M. (2010). Orígenes y propagación de la crisis internacional. En P. Leiva (Ed.), Impactos de la crisis internacional sobre la economía chilena (pp. 65-68). Santiago: LOM.

Arezki, R., Candelon, B. \& Sy, A. (2011). Derivaciones municipales. Finanzas y Desarrollo, 48(3), 3436. Disponible en http://bit.ly/174E9g4

Attali, J. (2009). ¿Y después de la crisis qué...? Propuestas para una nueva democracia mundial. Barcelona: Gedisa.

Banco Central de Chile (2011). Sector inmobiliario: implicancias para la estabilidad financiera. En Banco Central de Chile, Informe de Estabilidad Financiera (pp. 36-39). Santiago: Autor. Disponible en http://bit.ly/12ilL2F

Belil, M., Borja, J. \& Corti, M. (Eds.). (2012). Ciudades, una ecuación imposible. Buenos Aires: Ed. Café de las Ciudades.

Bernardos, G. (2009). Creación y destrucción de la burbuja inmobiliaria en España. ICE, 850, 23-40. Disponible en http://bit.ly/12gHdoH

Brown, D. (2000). Liquidity and liquidation: evidence from real estate investment trusts. Journal of Finance 55(1), 469-485. URL estable: http://www.jstor.org/stable/222563

Brueggemen, W. \& Fisher, J. (2004). Real Estate Finance and Investments. Boston: McGraw-Hill/Irwin.

Case, K. \& Shiller, R. (2003). Is there a bubble in the housing market? Brookings Papers on Economic Activity 2, 299-362. Disponible en http://bit.ly/12MU5hb

Cassidy, J. (2011). Como os mercados quebran. A lógica das catástrofes econômicas. Río de Janeiro: Intrínseca.

Corpataux, J., Crevoisier, O. \& Theurillat, T. (2009). The expansion of the finance industry and its impact on the economy: a territorial approach based on Swiss pension funds. Economic Geography, 85(3), 313-334. doi: 10.1111/j.1944-8287.2009.01035.x

Cohen, M. (2012). La ciudad en el contexto de la crisis mundial. En M. Belil, J. Borja \& M. Corti (Eds.), Ciudades, una ecuación imposible (pp. 35-58). Buenos Aires: Ed. Café de las Ciudades. Disponible en http://bit.ly/117q4aq

Colom, A. (2012). La crisis económica española: orígenes y consecuencias. Una aproximación crítica. XIII Jornadas de Economía Critica: Los costes de la crisis y alternativas en construcción (pp. 1314-1330). Sevilla, febrero de 2012. Disponible en http://bit.ly/12Oks6t.

Cortés, H. (2000). La arquitectura monetaria mundial. En H. Muñoz (Comp.), Globalización XXI. América Latina y los desafíos del nuevo milenio (pp. 183-196). Santiago: Aguilar.

Daher, A. (2004). Riesgo país versus riesgo región: Santiago en el Mercosur. En C. de Mattos et al. (Eds.), Santiago en la globalización: ¿una nueva ciudad? (pp. 85-113). Santiago: Ediciones SUR/EURE libros. Disponible en http://www.sitiosur.cl/r.php?id=17

De Mattos, C. (2007). Globalización, negocios inmobiliarios y transformación urbana. Nueva Sociedad, 212, 82-96. Disponible en http://www.nuso.org/upload/articulos/3481_1.pdf

Fernández-Tabales, A. \& Cruz, E. (2013). Análisis territorial del crecimiento y la crisis del sector de la construcción en España y la Comunidad Autónoma de Andalucía. EURE, 39(111), 5-37. doi: 10.4067/S0250-71612013000100001.

Foster, J. \& Magdoff, F. (2009). La gran crisis financiera. Causas y consecuencias. Madrid: Fondo de Cultura Económica. 
García, J. (2008). De la quimera inmobiliaria al colapso financiero. Crónica de un desenlace anunciado. Barcelona: Antoni Bosch.

Golub, Ph. (2010). Las capitales del capitalismo. De las ciudades-estado a la ciudad global. En Monde Diplomatique (Ed.), Las capitales del capitalismo. Ciudades. Urbanismo y desastre en Chile (pp. 25-30). Santiago: Editorial Aún creemos en los sueños.

González, M. (2011). La vivienda y la crisis. Extoikos, 3, 33-36. Disponible en http://www.extoikos. es/n3/pdf/extoikos3.pdf

Harvey, D. (2011). O enigma do capital e as crises do capitalismo. São Paulo: Boitempo.

Harvey, D. (2012). Las raíces urbanas de las crisis financieras. En M. Belil, J. Borja \& M. Corti (Eds.), Ciudades, una ecuación imposible (pp. 321-358). Buenos Aires: Ed. Café de las Ciudades.

Hiang Liow, K. (2008). Financial crisis and Asian real estate. Securities market interdependence: some additional evidence. Journal of Property Research, 25(2), 127-155. doi: $10.1080 / 09599910802605400$

Janoschka, M. (2011). Urbanismo neoliberal, expansión urbana y crisis financiera en el litoral español: Análisis empirico y reflexión crítica. Conferencia invitada en el marco del Simposio "Metrópolis en construcción. Cambios socioterritoriales y calidad de vida”. Santiago de Chile, 18 de octubre de 2011.

Johnson, R., Lizieri, C., Soenen, L. \& Worzala, E. (2006). Simulating currency risk on private investments in real estate. Journal of Real Estate Portfolio Management, 12(9), 91-102.

Jorion, P. (2008). La crise. Des subprimes au séisme financier planétaire. París: Fayard.

Krugman, P. (2010). De vuelta a la economía de la gran depresión y la crisis del 2008. Bogotá: Norma.

Laeven, L. \& Valencia, F. (2008). Systemic banking crises: a new database. IMF Working Paper WP/08/224. International Monetary Fund. Disponible en http://bit.ly/Ze9450

Leiva, P. (Ed.). (2010). Impactos de la crisis internacional sobre la economía chilena. Santiago: LOM.

Locussol, A. (2007). Krach 2007. La vague scélérate des "subprimes". París: Le Manuscrit.

Malpezzi, S. \& Wachter, S. (2005). The role of speculation in real estate cycles. Journal of Real Estate Literature, 13(2), 143-166.

Marichal, C. (2010). Nueva historia de las grandes crisis financieras. Una perspectiva global, 1873-2008. Buenos Aires: Debate.

Meen, E. (1996). Ten propositions in UK housing macroeconomics: an overview of the 1980s and early 1990s. Urban Studies, 33(3), 425-444. doi: 10.1080/00420989650011843

Ministerio de Vivienda (2010). Informe sobre la situación del sector de la vivienda en España. Ministerio de Vivienda, Gobierno de España, abril.

Moyano, E. (2010). Impactos de la crisis internacional en el sector exportador de Chile. En P. Leiva (Ed.), Impactos de la crisis internacional sobre la economía chilena (pp. 129-151). Santiago: LOM.

Muga, R. (2010). Impactos de la crisis internacional sobre los sectores productivos de Chile. En P. Leiva (Ed.), Impactos de la crisis internacional sobre la economía chilena (pp. 95-113). Santiago: LOM.

Naredo, J. M. (2012). El modelo inmobiliario español y sus consecuencias. En M. Belil, J. Borja \& M. Corti (Eds.), Ciudades, una ecuación imposible (pp. 65-98). Buenos Aires: Ed. Café de las Ciudades. Disponible en http://cafedelasciudades.com.ar/carajillo/7_art5.htm 
Ortega, E. \& Peñalosa, J. (2012). Claves de la crisis económica española y retos para crecer en la UEM. Documentos Ocasionales N ${ }^{\circ}$ 1201. Madrid: Banco de España, Eurosistema. Disponible en http://bit.ly/174NDrY

Rajan, R. \& Rancharam, R. (2011). Tierras en venta. Finanzas y Desarrollo, 48(4), 30-33. Disponible en http://bit.ly/13iwlSA

Ramonet, I. (2009). La catástrofe perfecta. Crisis del siglo y refundación del porvenir. Buenos Aires: Capital Intelectual.

Reinhart, C. \& Rogoff, K. (2008). Is the 2007 US subprime financial crisis so different? An international historical comparison. American Economic Review, 98(2), 339-344. doi: 10.1257/ aer.98.2.339

Reinhart, C. \& Rogoff, K. (2011). Esta vez es distinto: ocho siglos de necedad financiera. México, D.F.: Fondo de Cultura Económica.

Roubini, N. \& Mihm, S. (2010). Cómo salimos de ésta. Santiago: Destino.

Shiller, R. (2009). El estallido de la burbuja. Cómo se llegó a la crisis y cómo salir de ella. Barcelona: Gestión 2000.

Soros, G. (2008). El nuevo paradigma de los mercados financieros. Para entender la crisis económica actual. Buenos Aires: Taurus.

Stiglitz, J. (2010). Caida libre. El libre mercado y el hundimiento de la economía mundial. Buenos Aires: Taurus.

Vergés, R. (2002). El mercado residencial español 1987-2006. Expectativas de vivienda y suelo. Revista de Economía y Finanzas de Castilla y León, 6, 69-83. Disponible en http://www.ricardoverges.com/pdf/CyL2002.pdf

Wolff, E. (2006). International perspective on household wealth. Cheltenham: Edward Elgar.

Zandi, M. (2008). Financial Shock: a $360^{\circ}$ look at the subprime mortgage implosion, and how to avoid the next financial crisis. Upper Saddle River, NJ: Financial Time Press. 